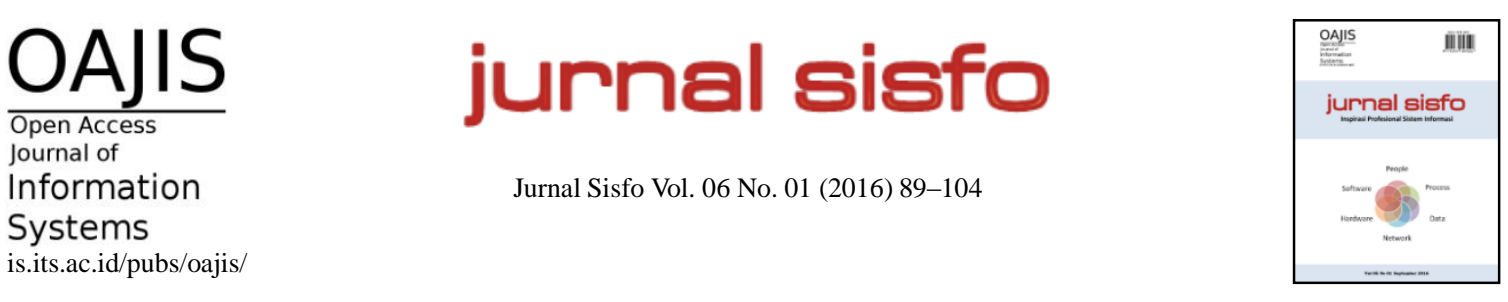

\title{
Pembangunan Sistem Informasi Sebaran Rumah Tangga Miskin Kelurahan Puhun Tembok Bukittinggi
}

\author{
Ulfa Fithriyyah, Fajril Akbar, ${ }^{*}$, Haris Suryamen \\ Jurusan Sistem Informasi, Fakultas Teknologi Informasi, Universitas Andalas
}

\begin{abstract}
Bukittinggi is one of the big cities in West Sumatra with a high poverty level. Bukittinggi is determined at fourth with $4.96 \%$ of the population is categorized as poor. It has 2,694 poor households that spread over three districts in 24 villages. Puhun Tembok is in the third place of the most are that settled by poor households. 163 families stay in this territory that has approximately $70.9 \mathrm{~km}^{2}$ in large. Scatterred location dan inaccurate information of each poor houseold cause improper poverty programme. Therefore, the location based information systems for poor households at Puhun Tembok implemented using web service. Waterfall adopted as software development method. This system has functional 7 functional need, including searching based on RW, donation received, searching the nearby poor households and routes to selected poor households. Functional need of this application is also tested by 5 users. The results show that 7 proposed functional need have been met by the application.
\end{abstract}

Keywords: Poor households, Geographic Information System, Web-GIS

\begin{abstract}
Abstrak
Kota Bukittinggi merupakan salah satu kota besar di Sumatera Barat dengan angka kemiskinan yang tinggi. Bukittinggi menempati urutan ke empat tertinggi Sumatera Barat dengan $4.96 \%$ dari jumlah penduduknya adalah penduduk miskin. Bukittinggi tercatat memiliki 2.694 rumah tangga miskin yang tersebar di 3 kecamatan dengan 24 kelurahan. Kelurahan Puhun Tembok menempati urutan ketiga tebanyak bagi rumah tangga miskin. 163 rumah tangga miskin yang ada tersebar pada wilayah yang memiliki luas kurang lebih $70,9 \mathrm{~km}^{2}$. Lokasi yang tersebar dan informasi setiap rumah tangga miskin yang tidak akurat mengakibatkan program pengentasaan kemiskinan menjadi tidak tepat sasaran. Oleh karena ini dibangunlah sistem informasi berdasarkan lokasi rumah tangga miskin Kelurahan Puhun Tembok yang berbasis web. Metode pengembangan perangkat lunak yang digunakan adalah metode waterfall. Aplikasi memiliki 7 kebutuhan fungsional, diantaranya pencarian rumah tangga miskin berdasarkan RW, bantuan yang diterima, pencarian rumah tangga miskin terdekat serta rute menuju rumah tangga miskin. Fungsional aplikasi diuji oleh 5 orang penguji. Hasil pengujian menunjukkan 7 kebutuhan fungsional yang dirancang telah dipenuhi oleh aplikasi.
\end{abstract}

Kata kunci: Rumah Tangga Miskin, Sistem Informasi Geografis, Web-GIS

() 2016 Jurnal SISFO.

Histori Artikel : Disubmit 16 Agustus 2016; Diterima 14 September 2016; Tersedia online 16 September 2016

\footnotetext{
* Corresponding Author

Email address: ijab@ft.unand.ac.id (Fajril Akbar)
} 


\section{Pendahuluan}

Kemiskinan merupakan suatu keadaan penduduk yang tidak mampu untuk memenuhi kebutuhan dasar minimal seperti makanan, pakaian, perumahan, pendidikan dan kesehatan untuk hidup yang layak. Kemiskinan dapat disebabkan oleh kelangkaan alat pemenuhan kebutuhan dasar, serta sulitnya akses terhadap pendidikan dan perkerjaan [1]. Menurut data Biro Pusat Statistik, Kota Bukittinggi di tahun 2014 menempati urutan ke empat tertinggi dari tujuh kota di Provinsi Sumatera Barat. Kota Bukittinggi memiliki 2.694 rumah tangga miskin dari 28.616 rumah tangga [2].

Kelurahan Puhun Tembok menempati urutan ketiga dalam jumlah rumah tangga miskin dari 24 kelurahan di Kota Bukitinggi. 163 rumah tangga miskin tersebar di Kelurahan Puhun Tembok dengan luas wilayah kurang lebih $70,9 \mathrm{~km}^{2}$. Luasnya wilayah dengan lokasi rumah tangga miskin yang tersebar menjadi salah satu kendala dalam program pengentasan kemiskinan di Bukittinggi. Salah satu faktor yang menyebabkan lambatnya penurunan angka kemiskinan akibat ketidaktepatan program pengentasan kemiskinan, ditambah lagi dengan kurangnya data yang akurat tentang kemiskinan di suatu wilayah [3]. Oleh karena itu, dibutuhkan sebuah sistem informasi yang mampu menampilkan lokasi setiap rumah tangga miskin bagi Kelurahan Puhun Tembok dan mudah diakses oleh penggunanya. peran sistem informasi untuk mengidentifikasi masyarakat miskin serta data-data rumah tangga miskin yang lengkap dan akurat sehingga bantuan yang disalurkan tepat pada sasaran [4].

Pengembangan suatu sistem identifikasi rumah tangga miskin dengan metode Analytical Hierachy Process (AHP) juga telah dilakukan di Kabupaten Bantul [4]. Hasil dari sistem tersebut di visualisasikan dengan memanfaatkan Sistem Informasi Geografis (SIG). Penggunaan MapServer untuk mengembangkan sistem informasi lokasi penduduk miskin bagi Kotamadya Pekanbaru, namun terkendala karena keterbatasan layanan peta yang digunakan [5]. Penggunaan layanan peta online seperti Google Maps, juga telah dilakukan dengan objek kajian penduduk miskin kota Samarinda dan Balikpapan. Fitur yang dikembangkan masih terbatas pada penyajian data spasial semata [6]. Sebuah model juga telah diteliti di kota Heichi, China yang menggunakan analisis spasial dengan SIG untuk mengevaluasi karakteristik kemiskinan multidimensi untuk berbagai kondisi geografis dan ekonomi yang berbeda [7]. Oleh karena itu, SIG mampu menjadi solusi dan media untuk mengidentifikasi penyebaran dan pemetaan rumah tangga miskin sehingga dapat dijadikan sumber informasi bagi penyaluran bantuan yang dari pemerintah terkait maupun pihak lainnya [4].

Pada penelitian ini, sistem yang dibangun adalah sistem informasi geografis yang berbasis web. Peta dasar yang digunakan adalah layanan peta online Google Maps yang diakses secara gratis. Dengan memanfaatkan Google Maps API (Aplication Programming Interface), peta Google Maps akan diintegrasikan kedalam aplikasi yang dibangun. Oleh karena ini, pada penelitian ini dirumuskan bagaimana membangun suatu sistem informasi berbasis web yang mampu memetakan penyebaran rumah tangga miskin di Kelurahan Tembok Kota Bukittinggi.

\section{Metodologi}

Pada penelitian ini metode pengembangan aplikasi mengadopsi metode Waterfall yang terdiri dari analisis, desain, pengodean dan pengujian. Pada tahapan analisis dilakukan analisis terhadap kebutuhankebutuhan fungsional dan non-fungsional dalam aplikasi web penyebaran rumah tangga miskin di Kelurahan Puhun Tembok Kota Bukittinggi. Pada tahap desain, dirumuskan rancangan arsitektur sistem, rancangan basis data, rancangan user interface, dan perancangan proses. Di tahapan pengodean dilakukan implementasi dari rancangan yang ada. Tahapan akhir adalah pengujuan terhadap aplikasi pemetaan penyebaran rumah tangga miskin di Kelurahan Puhun Tembok Kota Bukittinggi berbasis web. Pengujian dilakukan dengan menggunakan metode blackbox testing. Pengujian ini dilakukan untuk melihat kinerja 
dari sistem secara keseluruhan dengan cara membandingkan setiap fungsional yang dirumuskan telah sesuai dengan kemampuan aplikasi.

Data yang digunakan berupa data spasial dan data atribut. Data atribut yang digunakan pada penelitian ini bersumber dari Pendataan Program Perlindungan Sosial (PPLS) tahun 2011 yang dimiliki oleh Dinas Sosial dan Tenaga Kerja Kota Bukittinggi. Data atribut yang dikumpulkan berupa nama kepala keluarga, nomor kartu keluarga, nomor KTP kepala keluarga, alamat, jenis kelamin kepala keluarga, jumlah anggota keluarga, pendidikan terakhir kepala keluarga, pekerjaan kepala keluarga, pendapatan kepala keluarga, dan lain sebagainya. Data spasial diperoleh dari hasil digitasi peta udara Kota Bukittinggi dengan menggunakan aplikasi MapInfo Profesional. Data spasial ditampilkan pada peta dasar Google Maps. Aplikasi ini hanya bisa menyajikan data atribut yang telah tersimpan di basis data serta data spasial adalah hasil digitasi dari objek yang telah di observasi disetiap lokasi.

\section{Perancangan dan Implementasi Sistem}

\subsection{Analisis Kebutuhan}

Analisis kebutuhan pemetaan penyebaran rumah tangga miskin di Kelurahan Puhun Tembok Kota Bukittinggi berbasis web terdiri dari kebutuhan fungsional, kebutuhan non-fungsional, kebutuhan data spasial, use case diagram, context diagram, dan data flow diagram level 1. Kebutuhan fungsional untuk aplikasi pemetaan penyebaran rumah tangga miskin di Kelurahan Puhun Tembok Kota Bukitinggi berbasis web ini didapatkan dari analisis jurnal terkait[4][5][6] dan data PPLS 2011 maka didapatkan kebutuhan fungsional sebagai berikut:

1) Pengguna dapat melihat posisi saat ini pada peta.

2) Pengguna dapat melihat rumah tangga miskin terdekat dari posisi pengguna.

3) Pengguna dapat melihat rute dari posisi pengguna menuju rumah tangga miskin yang terpilih.

4) Pengguna dapat melakukan pencarian rumah tangga miskin berdasarkan RW.

5) Pengguna dapat melakukan pencarian rumah tangga miskin berdasarkan pekerjaan kepala keluarga.

6) Pengguna dapat melakukan pencarian rumah tangga miskin berdasarkan bantuan yang diterima.

7) Pengguna dapat melihat informasi rumah dari rumah tangga miskin

Kebutuhan non-fungsional pada sistem yang dibangun adalah sebagai berikut:

1) Sistem harus memiliki akses internet untuk peta online.

2) Sistem memerlukan perangkat keras atau perangkat lunak sebagai penunjuk lokasi terkini

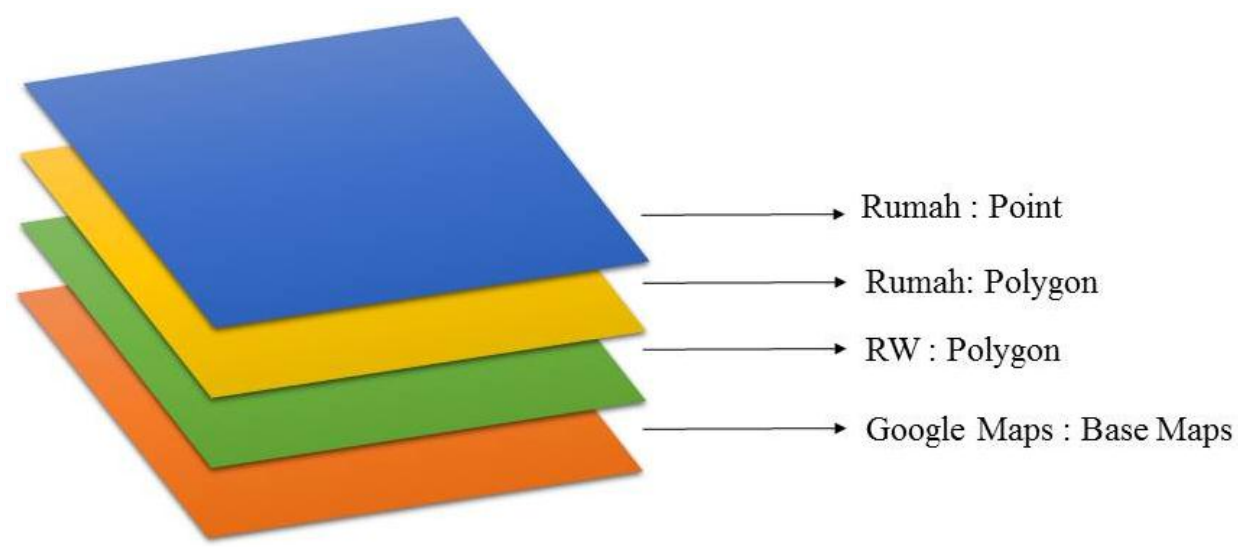

Gambar 1. Layer pemetaan penyebaran rumah tangga miskin 
Data spasial merupakan data yang berkaitan dengan aspek keruangan atau data yang berorientasi geografis seperti data koordinat dan ketinggian. Layer paling atas adalah berupa titik (point) sebagai titik posisi tengah dari objek rumah. Layer dibawahnya adalah berupa polygon untuk penunjuk bentuk dari rumah pada peta. Sedangkan untuk layer RW, digunakan polygon sebagai penunjuk batas wilayah RW pada base map. Kebutuhan data spasial pada aplikasi ini dapat dilihat pada Gambar 1.

\subsubsection{Use Case Diagram}

Use case diagram disusun berdasarkan kebutuhan fungsional sistem yang telah ditentukan sebelumnya. Use case diagram dari pembangunan sistem ini terdiri dari 1 aktor yaitu pengguna dan 7 use case. Pengguna dari aplikasi ini adalah instansi pemerintahan dengan fungsi-fungsi dari sistem adalah mampu melihat posisi terkini pada peta, melihat rumah tangga miskin terdekat dari posisi terkini, melihat rute dari posisi terkini ke rumah tangga miskin yang dipilih, mampu melakukan pencarian berdasarkan RW, melakukan pencarian berdasarkan pekerjaan kepala keluarga dan bantuan yang diterima serta mampu melihat informasi terkait pada setiap rumah tangga miskin. Use case diagram dari pembangunan sistem ini dapat dilihat pada Gambar 2.

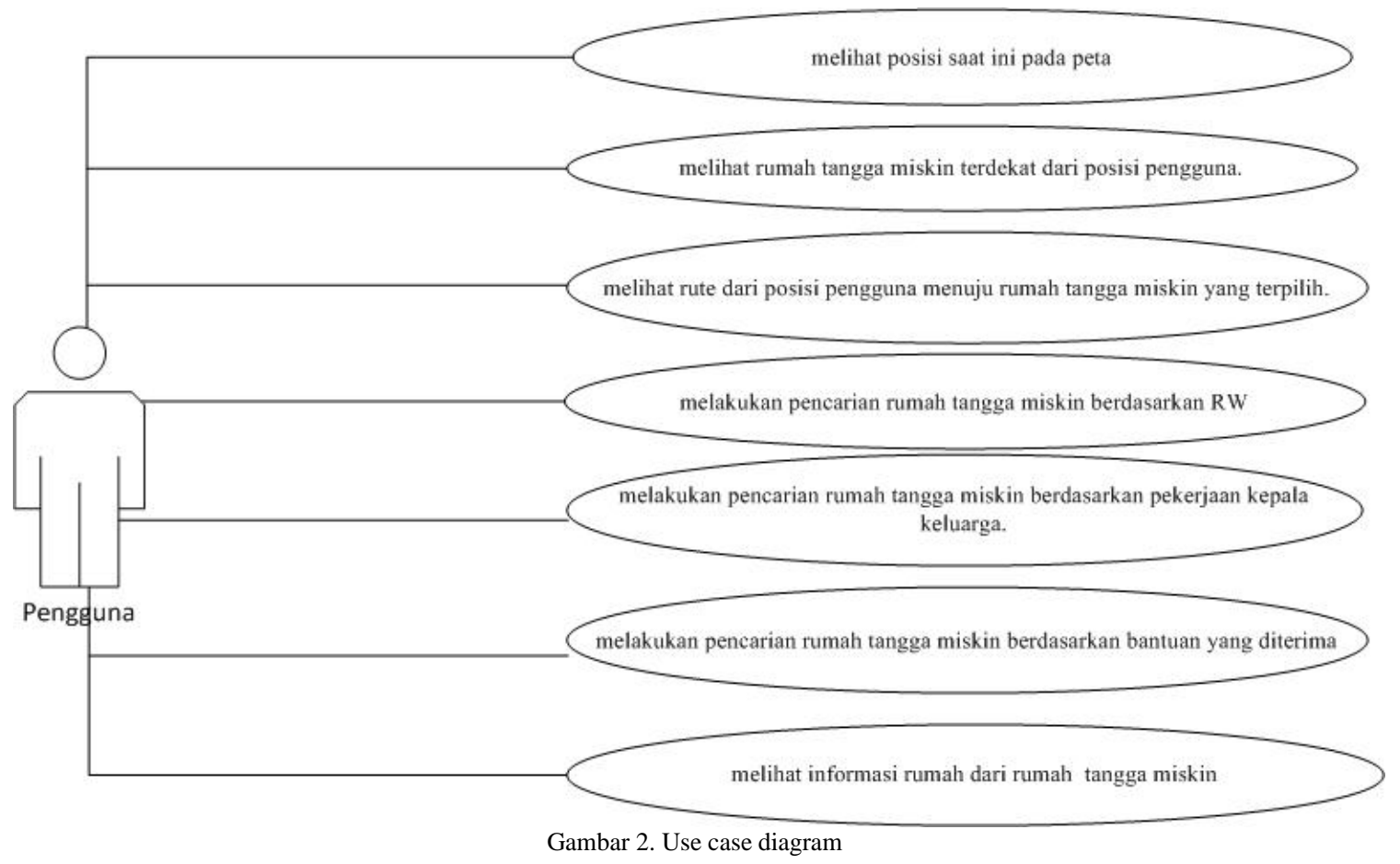

\subsubsection{Context Diagram}

Pada context diagram ini pengguna memberikan masukan kepada sistem berupa data request dan pengguna akan menerima keluaran dari sistem berupa data rumah tangga miskin. Sistem terdiri dari 2 entitas yaitu pengguna dan Google Maps. Pengguna memberikan masukan kepada sistem berupa permintaan data dan pengguna menerima keluaran dari sistem berupa data kepala keluarga, informasi rumah dan statistik rumah tangga miskin. Sedangkan, entitas Google Maps memberikan masukan berupa layanan peta dasar dan rute kepada sistem. Context diagram yang dirancang untuk pembangunan sistem ini dapat dilihat pada Gambar 3. 


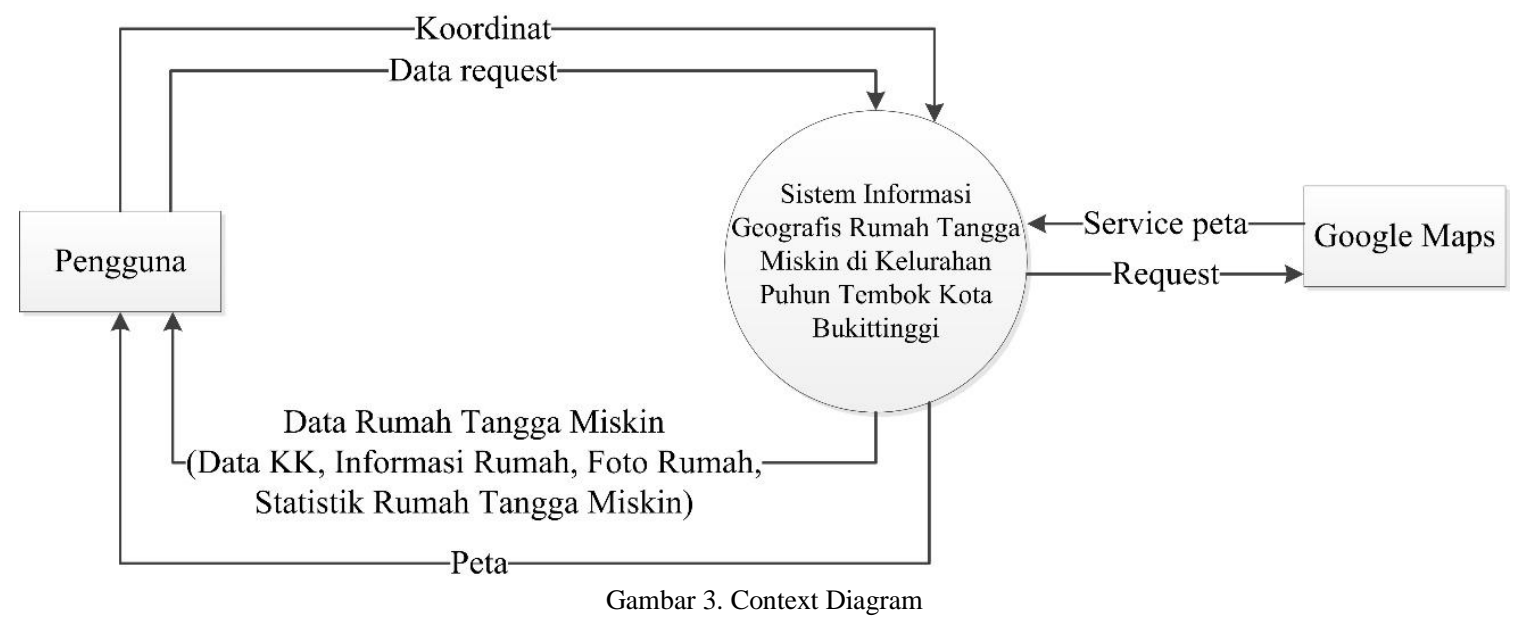

\subsection{Perancangan Sistem}

Perancangan sistem terdiri dari perancangan arsitektur sistem, perancangan basis data, perancangan user interface, dan perancangan proses.

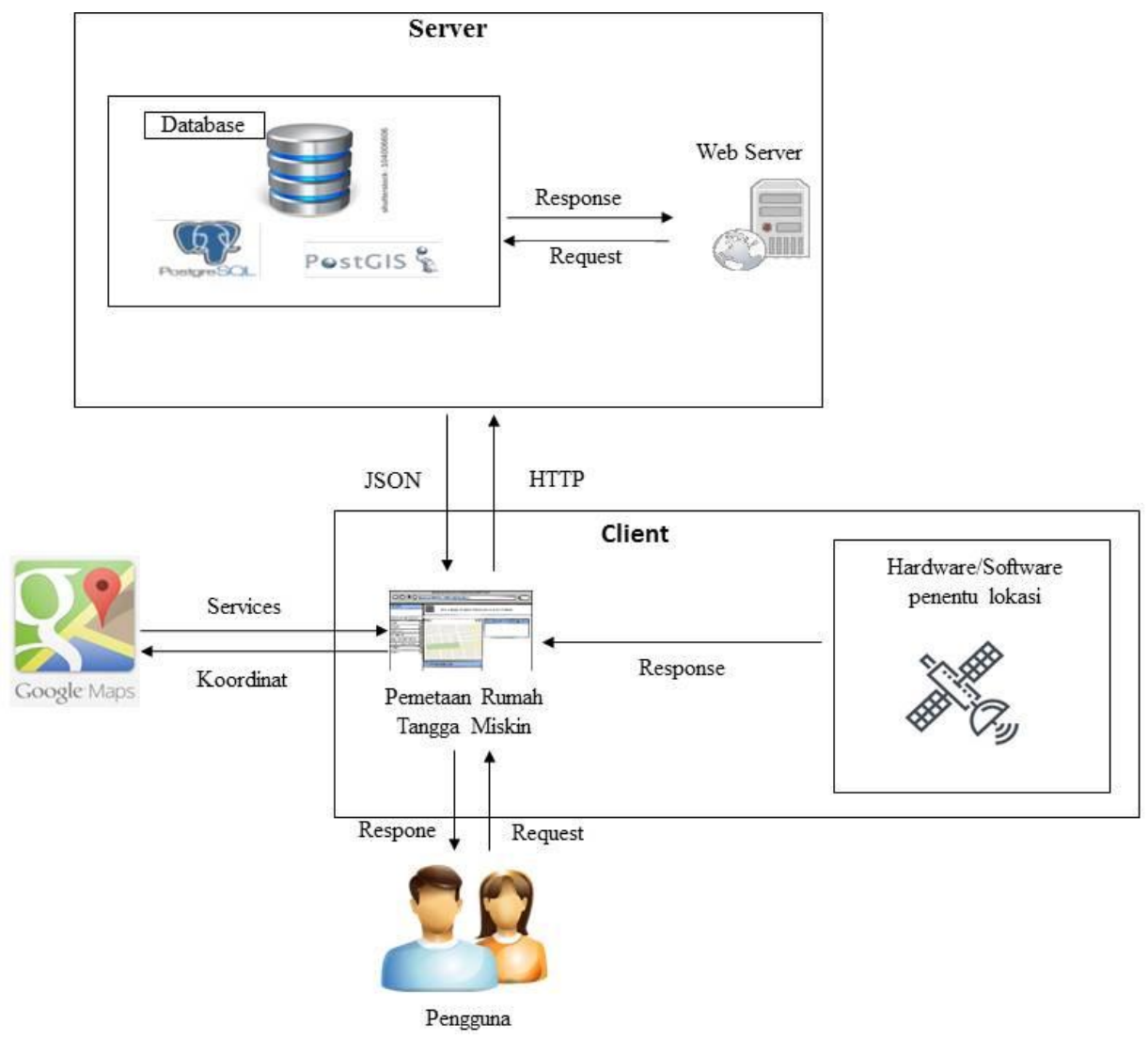

Gambar 4. Perancangan arsitektur sistem 
Ulfa Fithriyyah et al. / Jurnal SISFO Vol. 06 No. 01 (2016) 89-104

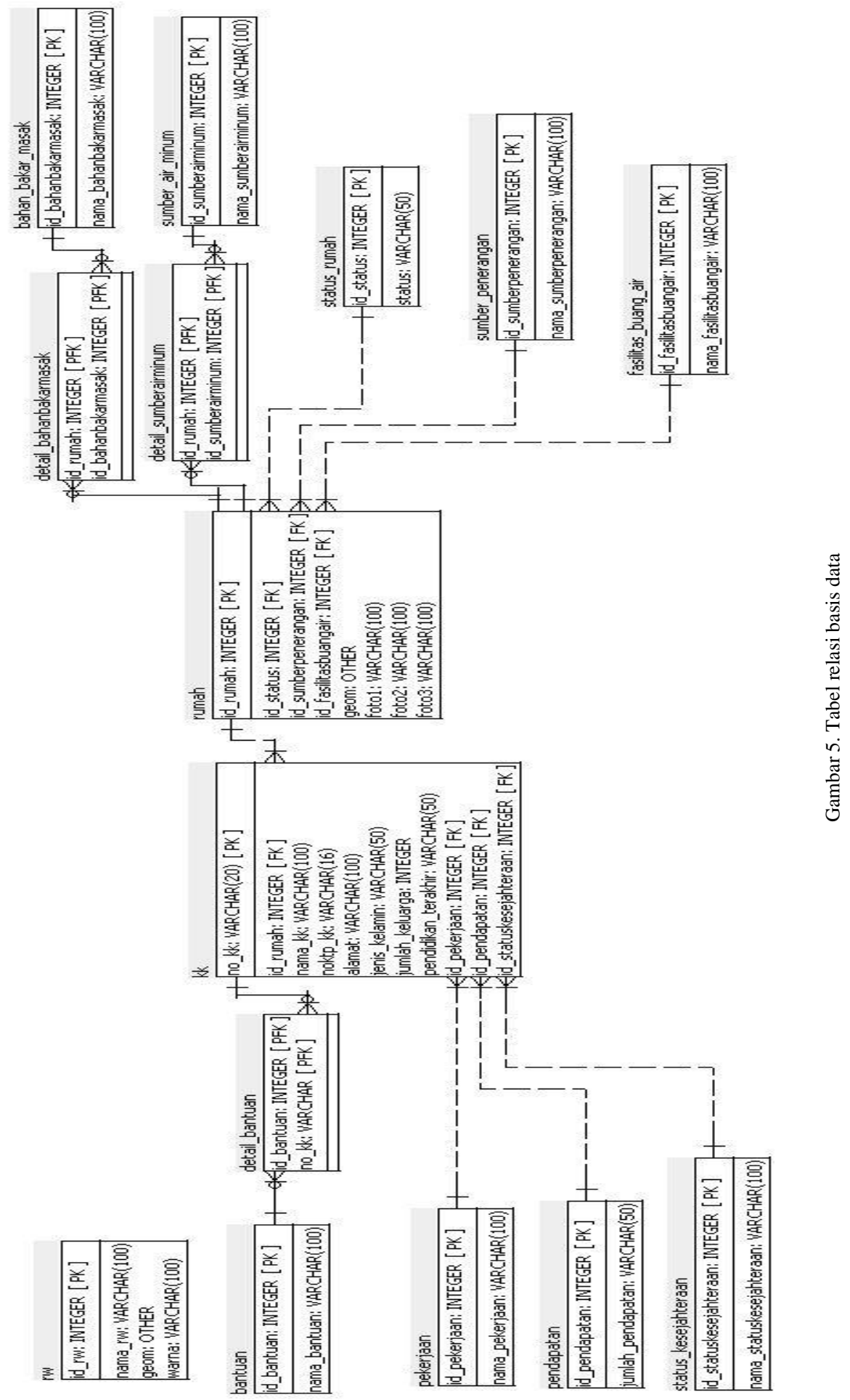




\subsubsection{Perancangan Arsitektur Sistem}

Rancangan arsitektur sistem pemetaan penyebaran rumah tangga miskin di Kelurahan Puhun Tembok Kota Bukittinggi berbasis web menggambarkan interaksi antara client dan server seperti pada Gambar 4 . Pada sisi server yang digunakan adalah web server untuk memberikan layanan data, basis data PostgreSQL dan ekstensinya PostGIS sebagai tempat penyimpanan data. Google Maps digunakan sebagai peta dasar aplikasi pemetaan penyebaran rumah tangga miskin di Kelurahan Puhun Tembok Kota Bukittinggi berbasis web. Sedangkan pada sisi client, yang digunakan adalah web browser untuk melakukan request dan response dari sistem.

\subsubsection{Rancangan Basis Data}

Basis data dari dibangun menggunakan PostgreSQL dengan ekstensi PostGIS untuk mendukung operasi spasial. Basis data yang dirancang untuk pemetaan penyebaran rumah tangga miskin di Kelurahan Puhun Tembok Kota Bukittinggi berbasis web terdiri dari lima belas tabel dengan field tertentu. Tabel relasi pada basis data dapat dilihat pada Gambar 5.

\subsubsection{Perancangan User Interface}

User interface yang dirancang antara lain halaman awal dan halaman informasi rumah. Halaman awal merupakan halaman yang pertama kali ditampilkan ketika pengguna mengakses aplikasi. Halaman ini dibagi menjadi 5 bagian yaitu, bagian atas, bagian kiri, bagian tengah, bagian kanan, dan bagian bawah. Bagian atas terdapat judul aplikasi. Bagian kiri terdapat menu pencarian. Bagian tengah terdapat peta dan informasi penduduk. Bagian kanan terdapat hasil pencarian rumah tangga miskin. Rancangan halaman informasi rumah memuat informasi rumah dari rumah tangga miskin yang dipilih. Informasi rumah yang mencakup status rumah, fasilitas Mandi Cuci Kakus (MCK), dan informasi lainnya terdapat pada bagian tengah halaman. Rancangan halaman awal dapat dilihat pada Gambar 6a dan informasi rumah dapat dilihat pada Gambar 6b.

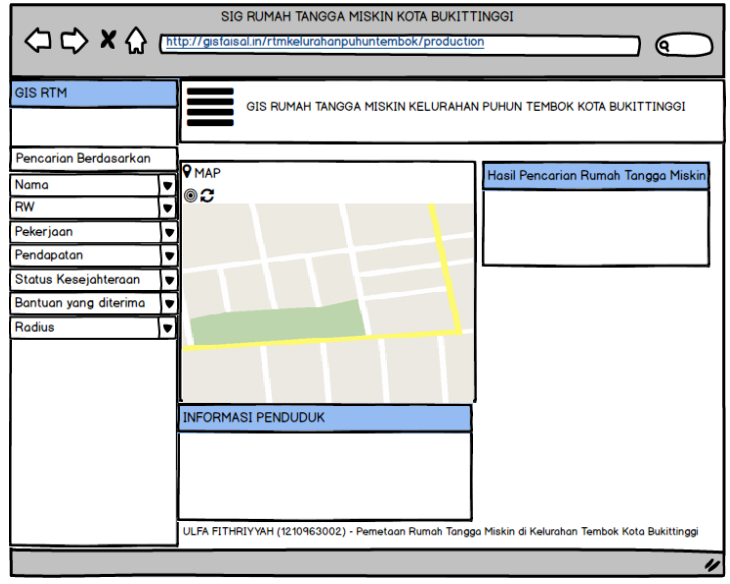

a) Halaman Awal

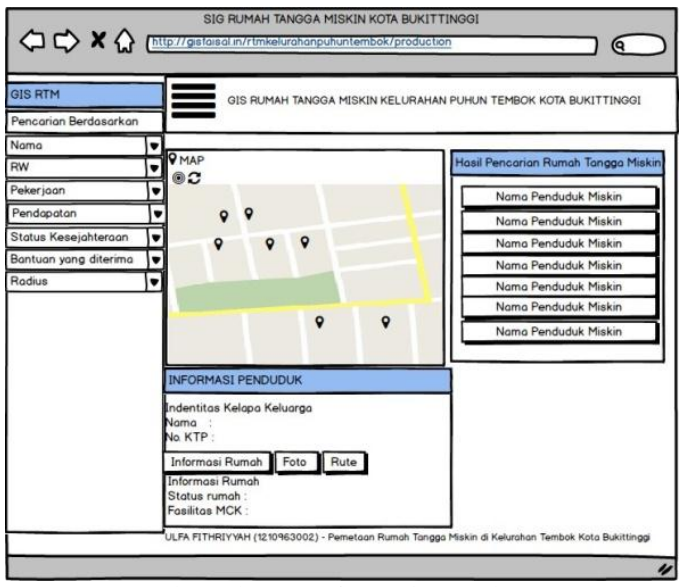

b) Halaman Informasi Rumah

Gambar 6. Rancangan user interface

\subsubsection{Rancangan Proses}

Rancangan proses ini menjelaskan apa yang dilakukan oleh pengguna dan apa reaksi yang diberikan oleh sistem terhadap suatu proses. Rancangan skenario ini menggambarkan urutan aktivitas yang digunakan untuk mencari rumah tangga miskin berdasarkan batuan yang diterima oleh rumah tangga miskin. Skenario ini dapat dilihat pada Tabel 1. 
Ulfa Fithriyyah et al. / Jurnal SISFO Vol. 06 No. 01 (2016) 89-104

Tabel 1. Skenario mencari rumah tangga miskin berdasarkan bantuan yang diterima

\begin{tabular}{|c|c|}
\hline Use Case Name & Mencari rumah tangga miskin berdasarkan bantuan yang diterima \\
\hline Participating Actor & Pengguna \\
\hline Flow of Event & $\begin{array}{l}\text { 1. Pengguna memilih menu pencarian rumah tangga miskin berdasarkan bantuan yang } \\
\text { diterima. } \\
\text { 2. Sistem menampilkan form pencarian. } \\
\text { 3. Pengguna memilih bantuan dengan mencentang pilihan. Pengguna dapat memilih lebih } \\
\text { dari satu pilihan bantuan. } \\
\text { 4. Sistem menampilkan data hasil pencarian. }\end{array}$ \\
\hline Entry Condition & Pengguna telah membuka aplikasi. \\
\hline Exit Condition & $\begin{array}{l}\text { Pengguna menerima hasil pencarian rumah tangga miskin berdasarkan bantuan yang } \\
\text { diterima. }\end{array}$ \\
\hline Alternative Scenario & $\begin{array}{l}\text { 1. Pengguna memilih bantuan dengan mencentang pilihan. Pengguna dapat memilih } \\
\text { lebih dari satu pilihan bantuan. } \\
\text { 2. Sistem memeriksa valid atau tidaknya data yang diiisi } \\
\text { 3. Sistem menampilkan pemberitahuan data tidak ada } \\
\text { 4. Pengguna memilih bantuan dengan mencentang pilihan. Pengguna dapat memilih } \\
\text { lebih dari satu pilihan bantuan. } \\
\text { 5. Sistem menampilkan data hasil pencarian. }\end{array}$ \\
\hline
\end{tabular}

\subsection{Implementasi Sistem}

Implementasi server untuk aplikasi pemetaan penyebaran rumah tangga miskin di Kelurahan Puhun Tembok Kota Bukittinggi berbasis web terdiri dari perangkat keras dan perangkat lunak. Untuk implementasi perangkat keras, aplikasi telah di instalasi pada perangkat server yang tersedia di internet dengan alamat IP adalah 205.251.137.35. Nama domain yang digunakan adalah http://gisfaisal.in/rtmbukittinggi/production.

Untuk perangkat lunak, basis data diimplementasikan dengan menggunakan PostgreSQL v9.3.0 beserta ekstensi PostGIS v2.1.0. Untuk tampilan user interface yang responsive, aplikasi juga memanfaatkan Bootstrap. Implementasi kode aplikasi menggunakan PHP dan JavaScript.

\subsection{Implementasi User Interface}

Halaman awal merupakan halaman yang pertama kali ditampilkan ketika pengguna mengakses web. Pada halaman ini menampilkan menu pencarian, peta, halaman untuk menampilkan hasil pencarian rumah tangga miskin, dan halaman untuk menampilkan informasi penduduk. Gambar 7 menampilkan hasil implementasi dari halaman awal.

Halaman Informasi Rumah ini memuat informasi dari rumah yang ditempati oleh rumah tangga miskin. Informasi rumah terdiri dari status rumah, fasilitas MCK, sumber penerangan, bahan bakar masak, dan sumber air minum. Implementasi halaman informasi rumah dapat dilihat pada Gambar 8. 


\section{Pengujian}

Pengujian pada sistem ini dilakukan menggunakan metode blackbox testing dengan mengamati masukan yang diberikan kepada sistem dan keluaran yang dihasilkan oleh sistem. Hasil pengujian sesuai jika keluaran yang dihasilkan oleh sistem sesuai dengan yang direncanakan. Pengujian sistem dilakukan pada aplikasi yang dibangun dan pengujian dilakukan oleh pihak yang tidak terkait dengan pembangunan aplikasi yang dibangun.
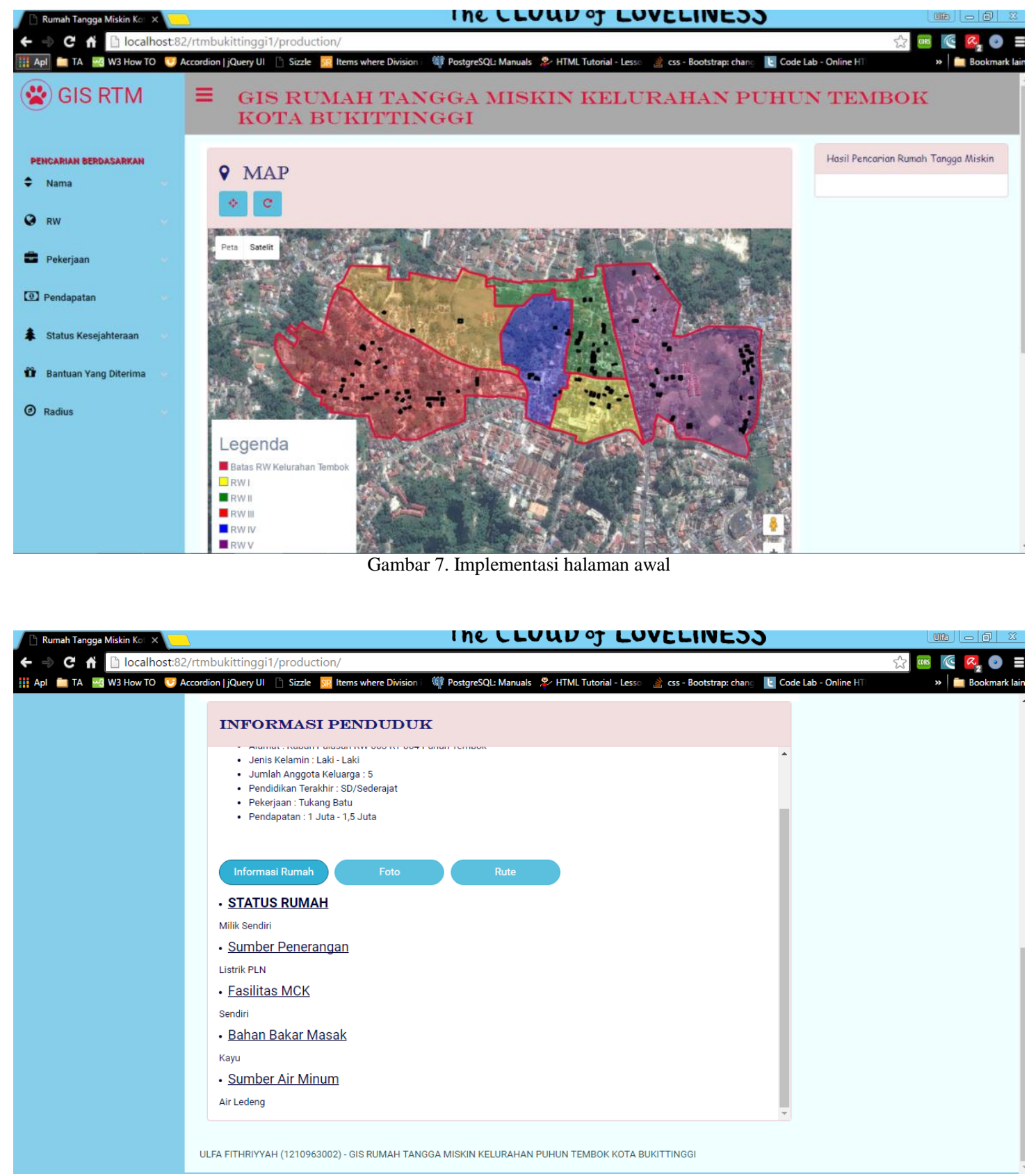

Gambar 8. Implementasi halaman informasi rumah 


\subsection{Pengujian Fungsional Mencari Rumah Tangga Miskin Berdasarkan Bantuan Diterima}

Pengujian yang dilakukan adalah mencari rumah tangga miskin berdasarkan bantuan yang diterima. Jenis bantuan yang diterima rumah tangga miskin adalah raskin yang memiliki id_bantuan adalah 1, Kartu Indonesia Sehat yang memiliki id_bantuan adalah 2, tidak ada yang memiliki id_bantuan adalah 3, lansia yang memiliki id_bantuan adalah 4, Kartu Indonesia Pintar yang memiliki id_bantuan adalah 5, penyandang cacat yang memiliki id_bantuan adalah 6, Kartu Kesejahteraan Sosial yang memiliki id_bantuan adalah 7, Bantuan Sosial yang memiliki id_bantuan adalah 8, dan PNPM rumah yang memiliki id_bantuan adalah 9. Hasil akhir dari pengujian ini adalah aplikasi menampilkan nama kepala keluarga berdasarkan bantuan yang dipilih oleh pengguna dan aplikasi menampilkan marker rumah tangga miskin tersebut pada peta. Pengujian juga dilakukan pada query $S Q L$ untuk melihat kesesuaian data yang ditampilkan aplikasi dengan data yang ada pada basis data. Prosedur pengujian mencari rumah tangga miskin berdasarkan bantuan diterima dapat dilihat pada Tabel 2. Gambar 9 merupakan hasil dari basis data untuk rumah tangga miskin berdasarkan bantuan yang diterima pada basis data. Hasil pengujian pencarian rumah tangga miskin berdasarkan bantuan yang diterima pada website untuk kasus dapat dilihat pada Gambar 10 yang diberi tanda lingkaran.

Tabel 2. Prosedur pengujian rumah tangga miskin berdasarkan bantuan yang diterima

\begin{tabular}{ll}
\hline Kasus dan hasil pengujian sukses \\
\hline Aksi & Pengguna memilih Kartu Indonesia Sehat dan Lansia \\
Ekspektasi & Muncul daftar nama kepala keluarga dan marker lokasi rumah tangga miskin \\
Hasil & Muncul daftar nama kepala keluarga dan marker lokasi rumah tangga miskin \\
Kesalahan & Tidak Ada \\
Pengujian & Sesuai \\
\hline
\end{tabular}

\begin{tabular}{|c|c|c|c|c|c|c|c|c|}
\hline \multicolumn{9}{|c|}{ Output pane } \\
\hline \multicolumn{2}{|c|}{ Data Output } & \multirow{2}{*}{$\begin{array}{l}\text { Explain } \\
\text { cter varyi }\end{array}$} & \multicolumn{2}{|c|}{ Messages } & \multicolumn{4}{|l|}{ History } \\
\hline & \multicolumn{2}{|c|}{$\begin{array}{l}\text { no_kk } \\
\text { character varying(20) }\end{array}$} & & \multicolumn{2}{|c|}{$\begin{array}{l}\text { nama_kk } \\
\text { character varying(100) }\end{array}$} & $\begin{array}{l}\text { geom } \\
\text { geometry(MultiPolygonZM) }\end{array}$ & $\begin{array}{l}\text { longitude } \\
\text { double precision }\end{array}$ & $\begin{array}{l}\text { latitude } \\
\text { double precision }\end{array}$ \\
\hline 1 & \multicolumn{3}{|c|}{1375020402150002} & \multicolumn{2}{|c|}{ Yuldiati } & $01060000 \mathrm{C} 0010000000103 \mathrm{C}$ & c) 361175847066 & -0.29710745896 \\
\hline 2 & \multicolumn{3}{|c|}{1375021503086413} & \multicolumn{2}{|c|}{ Yusniati } & $01060000 \mathrm{C} 0010000000103 \mathrm{C}$ & c). 361218807733 & -0.29780369540 \\
\hline 3 & \multicolumn{3}{|c|}{1375021702053138} & \multicolumn{2}{|c|}{ Sabirman ST. Jamari } & $01060000 \mathrm{C} 0010000000103 \mathrm{C}$ & c). 362390657143 & -0.29800516190 \\
\hline
\end{tabular}

Gambar 9. Hasil pengujian query $S Q L$ untuk mendapatkan rumah tangga miskin berdasarkan bantuan yang diterima

Kesimpulan dari hasil pengujian tersebut menunjukkan bahwa fungsional mencari rumah tangga miskin berdasarkan bantuan yang diterima pada website telah sesuai dengan yang direncanakan dan hasilnya sesuai dengan data yang ada dalam basis data.

Tabel 3. Prosedur pengujian melihat rumah tangga miskin terdekat dari posisi pengguna

\begin{tabular}{ll}
\hline Aksi & $\begin{array}{l}\text { Pengguna di titik koordinat }-0.305159,100.369515, \text { lalu klik tombol posisi saya saat ini. } \\
\text { Setelah itu pengguna memilih radius } 1000 \text { meter. }\end{array}$ \\
\hline Ekspektasi & $\begin{array}{l}\text { Muncul marker dan daftar nama kepala keluarga yang terdekat dari posisi pengguna sesuai } \\
\text { dengan jarak radius } 1000 \text { meter. }\end{array}$ \\
\hline
\end{tabular}


Hasil Muncul marker dan daftar nama kepala keluarga yang terdekat dari posisi pengguna sesuai dengan jarak radius 1000 meter.

\begin{tabular}{ll}
\hline Kesalahan & Tidak Ada \\
\hline Pengujian & Sesuai \\
\hline
\end{tabular}

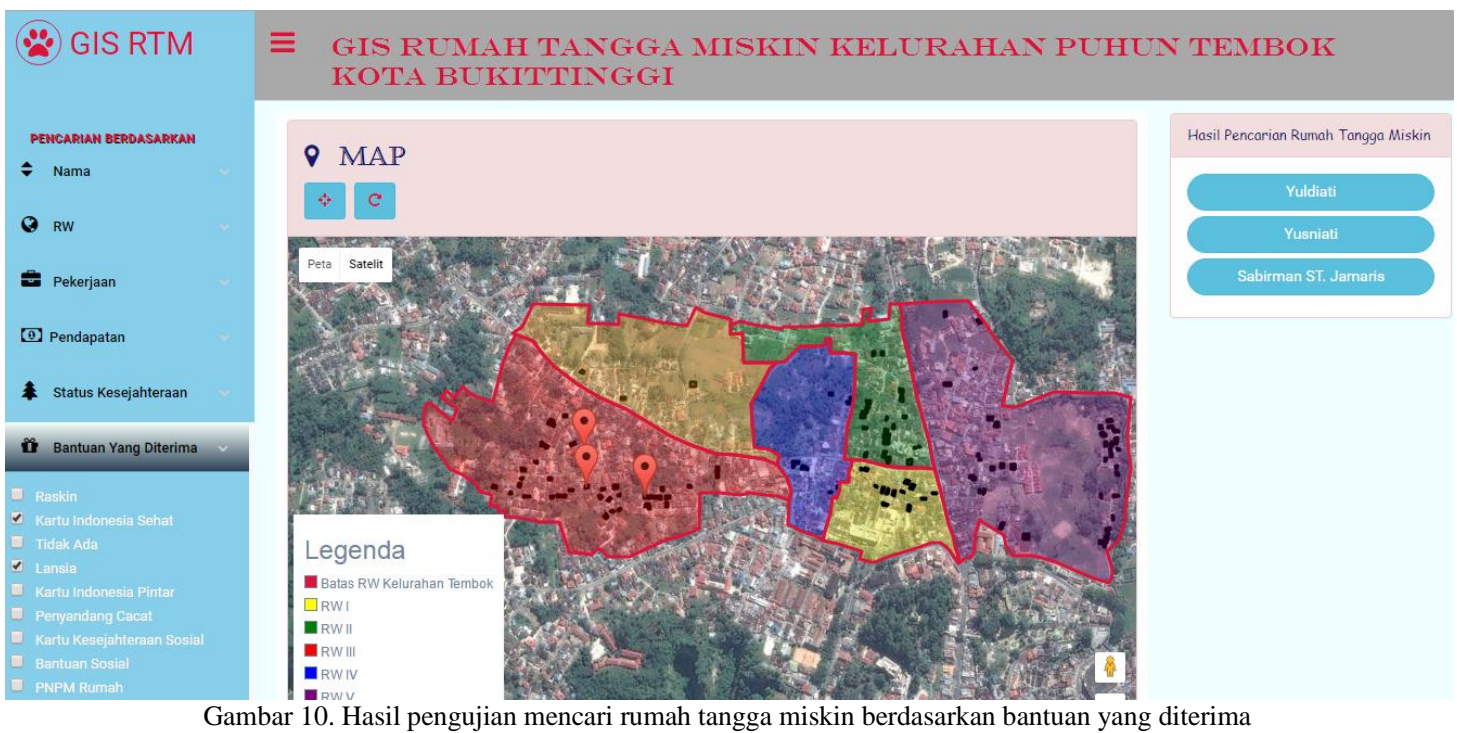

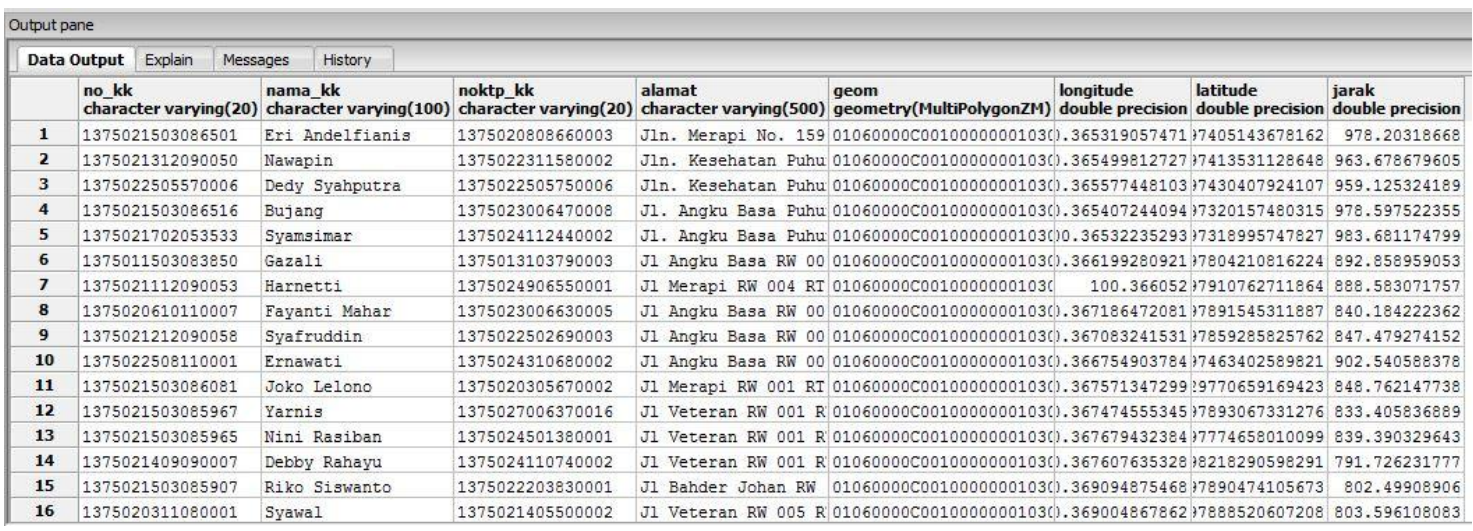
Gambar 11. Hasil SQL untuk mendapatkan rumah tangga miskin terdekat dari posisi pengguna

\subsection{Pengujian Fungsional Melihat Rumah Tangga Miskin Terdekat dari Posisi Pengguna}

Pengujian yang dilakukan adalah melihat rumah tangga miskin terdekat dari posisi pengguna. Pada pengujian ini, posisi pengguna ditetapkan pada $-0.305159,100.369515$. Setelah itu pengguna mengatur jarak yang diuji dalam radius kecil sama dengan 1000 meter dari posisi terkini. Hasil akhir dari pengujian ini adalah aplikasi menampilkan nama kepala keluarga berdasarkan posisi terdekat dari pengguna dan aplikasi menampilkan marker rumah tangga miskin tersebut pada peta. Hasil pengujian juga dibandingkan 
dengan keluaran basis data. Prosedur pengujian melihat rumah tangga miskin terdekat dari posisi pengguna dapat dilihat pada Tabel 3. Gambar 11 merupakan hasil query SQL untuk mendapatkan rumah tangga miskin terdekat dari posisi pengguna pada basis data. Hasil pengujian melihat rumah tangga miskin terdekat dari posisi pengguna pada website dapat dilihat pada Gambar 12.

Berdasarkan hasil pengujian, aplikasi telah mampu mengimplementasikan fungsional melihat rumah tangga miskin terdekat dari posisi pengguna pada website telah sesuai dengan yang direncanakan dan hasilnya sesuai dengan data yang ada dalam basis data.

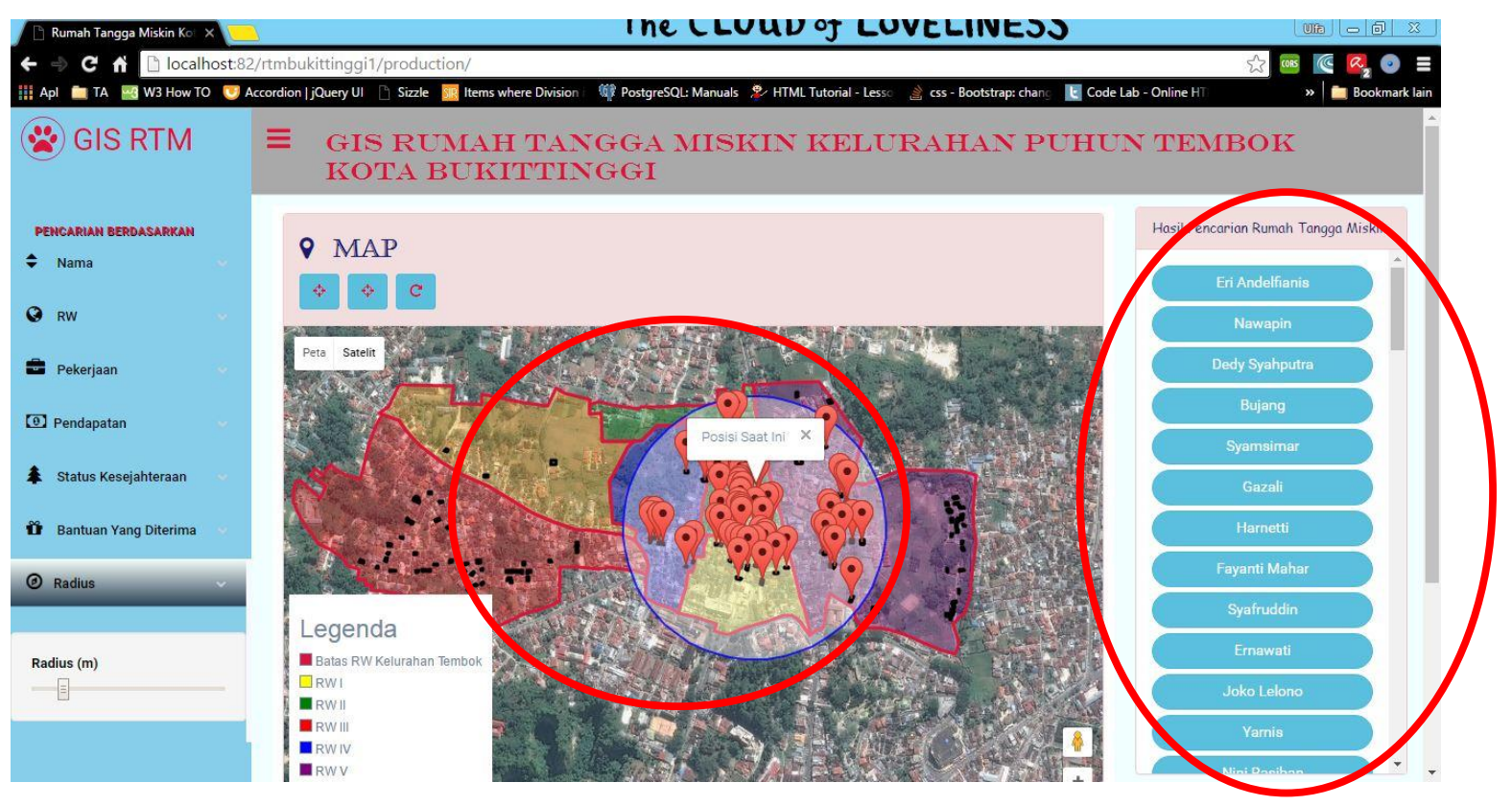

Gambar 12. Hasil pengujian mencari rumah tangga miskin terdekat dari posisi pengguna pada website

\subsection{Pengujian Fungsional Melihat Rute Dari Posisi Pengguna Menuju Rumah Tangga Miskin}

Pengujian yang dilakukan adalah melihat rute dari posisi pengguna menuju rumah tangga miskin yang dipilih. Posisi awal pengguna yang digunakan adalah $-0.305159,100.369515$. Prosedur pengujian melihat rute dari posisi pengguna menuju rumah tangga yang dipilih dapat dilihat pada Tabel 4. Hasil pengujian melihat rute dari posisi pengguna ditunjukkan oleh Gambar 13.

\begin{tabular}{ll} 
Tabel 4. Pengujian melihat rute dari posisi pengguna menuju rumah tangga yang dipilih \\
\hline Aksi & Pengguna memilih Rumah Nini Rasiban, lalu klik tombol rute \\
\hline Ekspektasi & Muncul rute dari posisi pengguna menuju rumah Nini Rasiban \\
\hline Hasil & Muncul rute dari posisi pengguna menuju rumah Nini Rasiban \\
\hline Kesalahan & Tidak Ada \\
\hline Pengujian & Sesuai \\
\hline
\end{tabular}




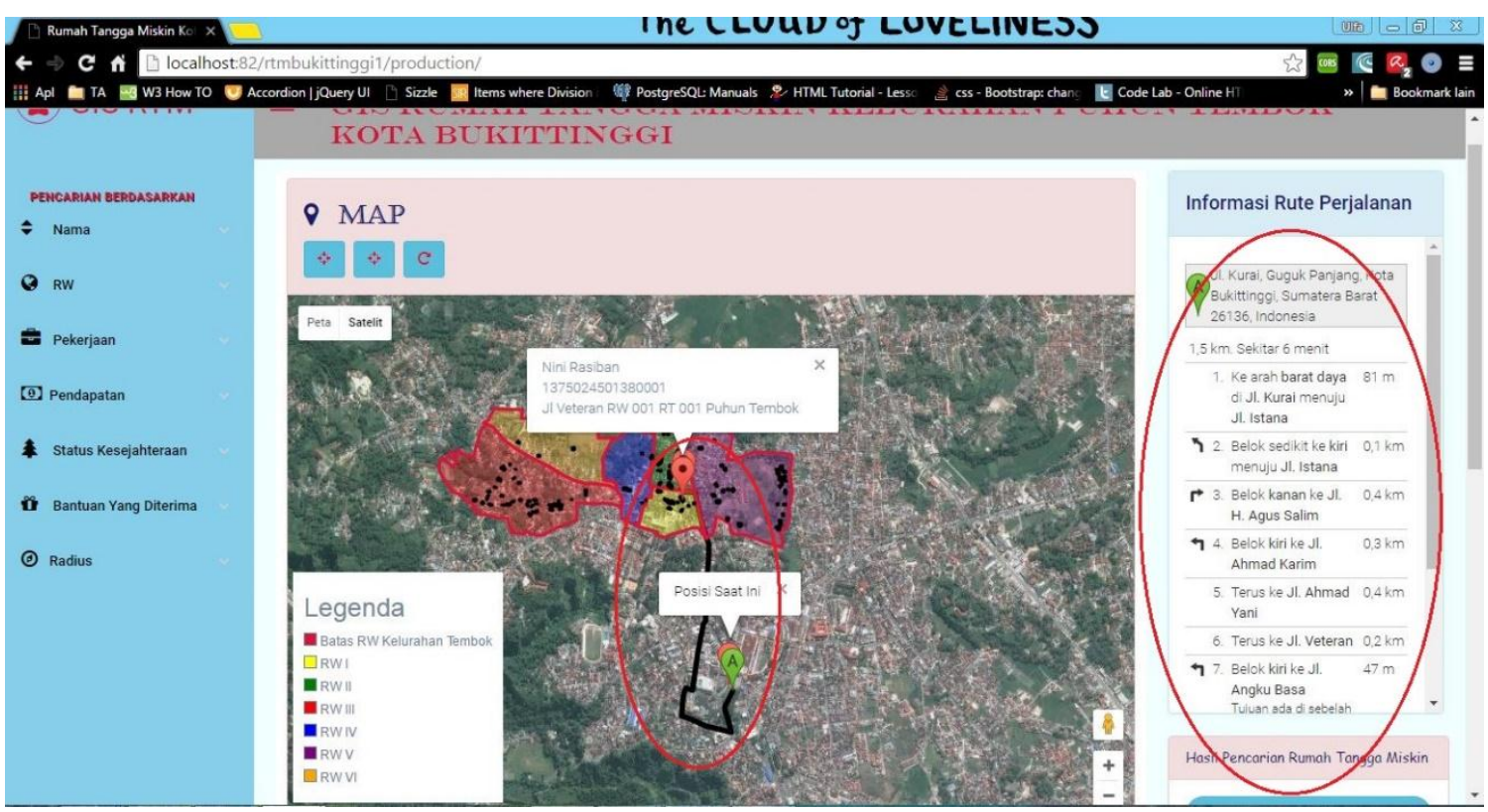

Gambar 13. Hasil pengujian melihat rute dari posisi pengguna menuju rumah tangga miskin yang terpilih Hasil dari pengujian tersebut menunjukkan bahwa fungsional melihat rute dari posisi pengguna menuju rumah tangga miskin yang dipilih telah sesuai dengan yang direncanakan.

\subsection{Pengujian User}

\section{From Pengujian Sistem}

Nama Sistem

Pemetaan Penyebaran Rumah Tangga Miskin di Kelurahan Puhun Tembok Kota Bukittinggi Berbasis Web

Nama Pembuat Sistem : Ulfa Fithriyyah

Nama Penguji Sistem : DIANA FAUZIAH, SH

Tanggal pengujian : 16 Aguctus 2016

\begin{tabular}{|c|c|c|c|c|c|}
\hline No & Fungsional & Aksi & Ekspektasi & Hasil* & Tanda Tangan \\
\hline 1. & Melihat posisi saat ini & $\begin{array}{l}\text { Pengguna mengklik } \\
\text { tombol posisi saya }\end{array}$ & $\begin{array}{l}\text { Peta dan marker posisi } \\
\text { saya saat ini muncul }\end{array}$ & Sesuai/Tidak-sestrai & \\
\hline 2. & $\begin{array}{l}\text { Mencari rumah tangga } \\
\text { miskin berdasarkan } \\
\text { nama kepala keluarga }\end{array}$ & $\begin{array}{l}\text { Pengguna mengetikan } \\
\text { nama kepala keluarga, } \\
\text { lalu klik tombol cari }\end{array}$ & $\begin{array}{l}\text { Muncul daftar nama kepala } \\
\text { keluarga dan marker lokasi } \\
\text { rumah tangga miskin }\end{array}$ & Sesuai/Tidak-sesuai & \\
\hline 3. & $\begin{array}{l}\text { Mencari rumah tangga } \\
\text { miskin berdasarkan } \mathrm{RW}\end{array}$ & $\begin{array}{l}\text { Pengguna memilih RW } \\
\text { lalu klik tombol cari }\end{array}$ & $\begin{array}{l}\text { Muncul daftar nama kepala } \\
\text { keluarga dan marker lokasi } \\
\text { rumah tangga miskin }\end{array}$ & Sesuai/Tidak-sestai & \\
\hline 4. & $\begin{array}{lr}\text { Mencari } & \text { rumah tangga } \\
\text { miskin } & \text { berdasarkan } \\
\text { pekerjaan } & \text { kepala } \\
\text { keluarga } & \\
\end{array}$ & $\begin{array}{lr}\text { Pengguna } & \text { memilih } \\
\text { pekerjaan, } & \text { lalu } \quad \text { klik } \\
\text { tombol cari } & \end{array}$ & $\begin{array}{l}\text { Muncul daftar nama kepala } \\
\text { keluarga dan marker lokasi } \\
\text { rumah tangga miskin }\end{array}$ & Sesuai/Tidak-sestai & \\
\hline
\end{tabular}

Gambar 14. Form hasil pengujian dari salah seorang tester 
Tabel 5. Rekapitulasi hasil pengujian dari penguji

\begin{tabular}{|c|c|c|c|c|c|}
\hline \multirow{2}{*}{ Fungsional } & \multicolumn{5}{|c|}{ Tester } \\
\hline & Lathifah Huda & Diana Fauziah & $\begin{array}{c}\text { Fachrul D } \\
\text { Herman }\end{array}$ & Fachrusy & $\begin{array}{l}\text { Mona } \\
\text { Astika }\end{array}$ \\
\hline Melihat posisi saat ini & Sesuai & Sesuai & Sesuai & Sesuai & Sesuai \\
\hline Pencarian berdasarkan RW & Sesuai & Sesuai & Sesuai & Sesuai & Sesuai \\
\hline Pencarian berdasarkan pendapatan & Sesuai & Sesuai & Sesuai & Sesuai & Sesuai \\
\hline Pencarian berdasarkan bantuan. & Sesuai & Sesuai & Sesuai & Sesuai & Sesuai \\
\hline $\begin{array}{l}\text { Melihat rumah tangga miskin terdekat } \\
\text { dari posisi pengguna. }\end{array}$ & Sesuai & Sesuai & Sesuai & Sesuai & Sesuai \\
\hline $\begin{array}{l}\text { Melihat informasi rumah tangga keluarga } \\
\text { miskin. }\end{array}$ & Sesuai & Sesuai & Sesuai & Sesuai & Sesuai \\
\hline $\begin{array}{l}\text { Melihat rute menuju rumah tangga miskin } \\
\text { dari posisi pengguna saat ini. }\end{array}$ & Sesuai & Sesuai & Sesuai & Sesuai & Sesuai \\
\hline
\end{tabular}

Analisis sistem secara keseluruhan menunjukkan bahwa penelitian ini telah dibangun dan dapat diakses pada alamat Aplikasi dapat diakses di http://gisfaisal.in/rtmbukittinggi/production. Teknik pengujian dilakukan dengan menggunakan metode blackbox testing. Pengguna menjalankan atau mengeksekusi setiap fungsional yang dirancang sesuai skenario, kemudian penguji mengamati luaran dari aplikasi. Hasil pengujian dari salah seorang penguji dapat dilihat pada Gambar 14. Tabel 5 menyajikan rekapitulasi pengujian fungsional oleh 5 orang penguji. Berdasarkan hasil pengujian yang telah dilakukan pada fungsional pemetaan penyebaran rumah tangga miskin Kelurahan Puhun Tembok diperoleh hasil bahwa 7 kebutuhan fungsional yang di rencanakan telah dipenuhi oleh aplikasi yang dibangun.

\section{Kesimpulan}

Sistem pemetaan penyebaran rumah tangga miskin di Kelurahan Puhun Tembok Kota Bukittinggi berbasis web telah selesai dibangun dengan menerapkan metode waterfall yang meliputi tahap analisis, desain, pengodean, dan pengujian. Dari hasil ini diuraikan hal-hal sebagai berikut:

1) Analisis kebutuhan fungsional dilakukan dengan cara menganalisis jurnal terkait dan data PPLS 2011. Hasil dari analisis tersebut didapatkan 7 kebutuhan fungsional yang dibangun pada sistem pemetaan penyebaran rumah tangga miskin di Kelurahan Puhun Tembok Kota Bukittinggi berbasis web.

2) Pemetaan penyebaran rumah tangga miskin di Kelurahan Puhun Tembok Kota Bukittinggi berbasis web telah dibangun dengan menggunakan metode waterfall. Analisis yang dilakukan terdiri dari analisis kebutuhan fungsional, kebutuhan non-fungsional, kebutuhan data spasial, use case diagram, context diagram, data flow diagram level 1. Sistem yang dibangun melibatkan satu aktor dan 7 use case, 15 Tabel yang digunakan untuk membangun basis data, dan 7 halaman yang telah dirancang sebagai antar muka aplikasi. Aplikasi dapat diakses di http://gisfaisal.in/rtmbukittinggi/production.

3) Pengujian telah dilakukan dengan menggunakan metode blackbox testing yang berfokus pada 7 fungsional dari sistem. Berdasarkan perbandingan output aplikasi dan data dari basis data serta pengujian oleh lima orang penguji, diperoleh hasil bahwa 7 kebutuhan fungsional yang dirancang tersebut telah berjalan sesuai dengan yang direncanakan. 


\section{Daftar Rujukan}

[1] SPKD Kota Bukittinggi, 2013. Strategi Penanggulangan Kemiskinan Daerah (SPKD) Kota Bukittinggi Tahun 2013[Online] Available at: http://www.bukittinggikota.go.id/index.php?class=text\&file_id=357. [Accessed 3 April 2016]

[2] Badan Pusat Statistik, 2013. Jumlah Penduduk Miskin Kota Bukittinggi [Online](Updated ..)

Available at: https://bukittinggikota.bps.go.id/linkTableDinamis/view/id/12. [Accessed 3 April 2016]

[3] Sunandi, E., 2014. Analisis statistika deskriptif dalam pemetaan kemiskinan di kota bengkulu. FMIPA Universitas Bengkulu

[4] Redjeki, S., Guntara, M. and Anggoro, P., 2014. Perancangan Sistem Identifikasi dan Pemetaan Potensi Kemiskinan untuk Optimalisasi Program Kemiskinan. Jurnal Sistem Informasi, 6(2).

[5] Mardiana, R., 2011. Sistem informasi penduduk miskin berbasis gis (Studi Kasus: Kotamadya Pekanbaru) (Doctoral dissertation, Universitas Islam Negeri Sultan Syarif Kasim Riau).

[6] Yanuartha, W., Fadli, M., dan Hatta, M.,2012. Pengembangan Sistem Peta Digital Tentang Sebaran Penduduk Miskin Di Kalimantan Timur (Studi Kasus Kota Samarinda Dan Balikpapan). STIMIK SPB Airlangga Samarinda

[7] Wang, Y., \& Wang, B. (2016). Multidimensional poverty measure and analysis: a case study from Hechi City, China. SpringerPlus, 5(1), 1-25. 
Ulfa Fithriyyah et al. / Jurnal SISFO Vol. 06 No. 01 (2016) 89-104

Halaman ini sengaja dikosongkan 